\title{
The Spanish Labour Foundation: The case of Construction Labour Foundation of Asturias
}

\author{
Dr. Daniel Pérez del Prado \\ Associate Professor \\ Universidad Carlos III de Madrid - ORCID: 0000-0001-7106-6769
}

Recibido: 09.05.2016

Aceptado: 11.06 .2016

DOI: http://dx.doi.org/10.20318/sllerj.2016.3311

\begin{abstract}
Work foundations are not well known institutions having a great potential to promote an improved and stronger social dialogue, worker participation and employee social responsibility. Perhaps, the Austrian work foundations are the most well known, serving as an example of success that may become the basis of a new model that is founded on flexicurity. However, there are other experiences in Europe from which knowledge may also be derived for both European and national good practices perspectives.

The purpose of this research is to analyse the main characteristics of Spanish labour foundations. The interest in these foundations is based on two main points. On the one hand, they give us a concrete and specific regulation on labour foundations which comes directly from the law. In this sense, they are based on a completely different legal system as compared to the Austrian experience. On the other hand, they represent the first regulation in Europe on this specific type of foundation. This not only means a longer tradition, but more importantly, that they are based on a completely different socio-economic perspective.

This paper has been divided as follows: first, there is a brief description of the concept of labour foundation; second, the regulatory framework is described, which consists of both the legal regulation and its practical manifestation. As for the latter, one of the most thorough and developed experiences has been chosen: the case of Construction Labour Foundation of Asturias. Finally, some conclusions about the practical development of labour foundations in Spain are offered.
\end{abstract}

Keywords: labour foundations, work foundations, Labour Law.

\section{Introduction: from "foundations" to "labour foundations"}

There is no existing common legal definition of the term "foundation", even in Europe. Countries with civil law systems recognize the foundation as a legal form, but its limits differ from one country to another. They are based on the ancient universitas rerum, which explains that the most important thing when defining a foundation is the patrimony or assets, which is destined to a specific purpose. Most common law countries, including the UK, Ireland, Cyprus and Australia, do not have a specific defini-

\footnotetext{
${ }^{*}$ The author wants to express his gratitude for the help and support given by the Fundación Laboral de la Construcción de Asturias (FLCA), Manuel García Rubio and Armando Adeba García. This research has been possible thanks to their collaboration. He also wants to recognize the help given by the European Foundation Centre and its staff in Brussels and the Asociación Española de Fundaciones. This article forms part of the research project "Evaluación sustantiva de las reformas laborales: una nueva metodología interdisciplinar" (DER 2012-33178).
} 
tion, but they use the "trust" concept, that is, a relationship between property and trusties, and follow its legal development from case law. The exception is the US, which in 1969 established a precise, albeit negative, definition ${ }^{1}$.

This heterogenic situation comes not only from the different legal traditions, but also from the distinct political systems and the role that foundations play in them. Despite its basis in private law, its development is quite close to the role displayed by the State. In economic terms, foundations are tools to "fill gaps" or cover market failures ${ }^{2}$, so they are inevitably destined to converge with the state, which usually carries out the same function. Some research underlies the role of foundations as a complement or substitute of the state (and sometimes, as a rival) ${ }^{3}$ and, accordingly, it establishes different roles depending on the "type" of the state 4

Therefore, it is possible to find different types of models («visions»), depending on the kind of relationship existing between the foundation and the state ${ }^{5}$. In the «social democratic model», foundations exist in a highly developed welfare state, which is not an obstacle to the quite intense activity, as a part of a coordinated relationship that allows them to play a complementary or supplementary role to that of the public authorities. In the so-called «state-controlled model», foundations are looked upon with suspicion, so they must carry out their activities within a quite controlling legal framework in a subservient level to the state. In practical terms, this model is quite closed to the «peripheral model», where foundations have a minor role, what is not necessary linked to the regulation, but with other reasons like social perception of foundations. Both may be seen as a more restrictive version of a «corporatist model», in which foundations have a subsidiary relationship with the state, and therefore, they are considered to be a part of the welfare state and not "strange" elements. In the «liberal model», foundations have quite an important space, but in a parallel system, next to the government, they are often an alternative to the mainstream and safeguards of non-majoritarian preferences. Finally, in the «business model», foundations are corporate instruments for achieving some public interest, thus cooperation relationships emerge not with the state, but with the business sector ${ }^{6}$.

Nevertheless, considering the common elements, some definitions have been provided. Focusing on legal requirements that appear in all legal systems, foundations have been termed «independent, separately-constituted non-profit bodies with their own established and reliable source of income, usually, but no exclusively, from an endowment, and their own governing board» ${ }^{7}$. In a most basic form, which underlines the role or purpose of this legal institution, «the foundation is based on the transfer of property from a donor to an independent institution having the obligation of using this property, and any proceeds derived from it, for a specified purpose or purposes during an often-undetermined period

\footnotetext{
${ }^{1}$ ANHEIER, H. K. Nonprofit organizations: theory, management, policy, Routledge, London; New York, NY, 2005, p. 304.

${ }^{2}$ WeIsBrod, B. A. The nonprofit economy, Harvard University Press, Cambridge, Mass., 1988.

${ }^{3}$ AnHeier, H. K.; Daly, S. "Comparing foundation roles", in Foundations in Europe: society, management and law, Routledge, New York, 2007, pp. 27-41. Currently, in this study, other kinds of roles carried out by foundations are explained.

${ }^{4}$ These studies are inspired by Sping-Andersen's construction of the Welfare State. G. Esping-Andersen, The three worlds of welfare capitalism, Princeton University Press, Princeton, N.J., 1990.

${ }^{5}$ AnheIER, H. K.; Daly, S. "Comparing foundations visions", in Foundations in Europe: society, management and law, Routledge, New York, 2007, pp. 45-58.

${ }^{6}$ Two more models may be added. The Mediterranean model, situated in the countries of Southern Europe and characterized by a huge increase in foundations over recent years; and the post-socialist model, typical in Eastern Europe and supported by external funds and forming part of a political, though highly complex and ambiguous agenda of public sector support. H. K. ANHEIER, "Foundations in Europe: a comparative perspective", en Foundations in Europe: society, management and law, The Directory of Social Change, London, 2001, pp. 68-75.

${ }^{7}$ European Foundation Centre, Comparative Highlights of Foundation Laws. The Operating Environment for Foundations in Europe, EFC, Brussels, 2015, p. 8. This reports analyses the regulation of foundations in 40 European countries from a cross-national perspective, focusing on the following common elements: 1) purpose of a foundation, 2) minimum capital, 3) state approval, 4) registration, 4) economic activities, 6) majority shareholding, 7) governing organs, 8) remuneration of board members, 9) reporting, 10) external audit, 11) supervisory authorities, 12) recognition of foreign foundations, 13) assets and dissolution, 14) administration cost, 15) timely disbursement of income and assets, 16) activities abroad and implications for the tax status, 17) gift and inheritance tax, 18) tax treatment of income from grants and donations, 19) tax treatment of income from asset administration and economic activities, 20) tax treatment of foreign-based foundations, 21) tax treatment of individual donors-domestic and cross-border cases, 22) tax treatment of corporate donors-domestic and cross-border, 23) overview of core elements of the legal requirements for public benefit tax status, 24) overview of purposes for exempt public-benefit status.
} 
of time» ${ }^{8}$ or «a private legal entity that possesses income-generating assets and devotes its resources to public purposes» ${ }^{9}$.

Accordingly, a foundation must have the following characteristics ${ }^{10}:$ i) it must be an asset-based entity or a non membership-based organization, which means that it is based on an original deed that provides both the intent of purpose and relative permanence as an organization; ii) it must be a private entity, which does not mean that it can belong to the State, but it is structurally separate from public bodies and it cannot exercise governmental authority; iii) it must be a self-governing entity, so it must be provided by its own governing bodies; iv) it must be a non-profit-distributed entity, so it is not to return profits to their owners or members; v) it must serve a public purpose, which is understood to be a purpose of general interest; and vi) self-understanding and identity as "foundation", distinguishing it to other non-profit organizations. All these items permit distinguish a foundation to other philanthropic entities throughout countries despite of the lack of a single legal definition.

In spite of this huge variety, all foundations may be classified into three different types, according to their activity ${ }^{11}$ : i) grant-making foundations, which provide funds for specific purposes; ii) operating foundations, which primarily operate their own programs; iii) and mixed foundations, which combine these two kind of activities. If we pay attention to founder type, four different kinds may be distinguished: i) individual foundations, in which the founder is a natural person (or persons); ii) corporate foundations, the most common of which are company related or company sponsored ones; iii) community foundations, which quite common in Anglo-Saxon countries and usually belongs to municipalities; and iv) government-sponsored or government-created foundations, if they receive a lot of support from the state ${ }^{12}$.

According to this brief description, there is no relationship between foundations and labour issues apparently. Labour foundations do not appear in the list of kinds of foundations; neither employers nor employees are mentioned as possible founders; working conditions and social protection do not seem to be the prototypical types of activities carried out by them. However, Labour Law is an area of confluence between the public and the private issues and, therefore, plenty of general interest must be defended ${ }^{13}$. This is a field in which the State intervenes but also, in which social partners, employers and employees, plays a very significant role. From this perspective, labour foundations can be a tool on hand for those who are closer to the labour market to develop the activities that every legal system attributes to them. This makes Labour and Social Security Law an appropriate field for the development of labour foundations ${ }^{14}$.

Work foundations ${ }^{15}$ are not well known institutions having a great potential to promote an improved and stronger social dialogue, worker participation and employee social responsibility. Perhaps, the Austrian work foundations are the most well known, serving as an example of success that may become the basis of a new model that is founded on flexicurity ${ }^{16}$. They were born out of a truly specific context that determines their subsequent development. Specifically, the first labour foundation, the Steel Foundation was created in the 1980 ' $\mathrm{s}^{17}$, using as an example, the experiences from other German industrial $\operatorname{areas}^{18}$. The purpose of this legal tool is to reconvert the most important Austrian steel company,

\footnotetext{
${ }^{8}$ ANHEIER, H. K. Nonprofit organizations, cit., p. 304.

${ }^{9}$ AnHEIER, H. K. "Foundations in Europe: a comparative perspective", cit., p. 2. See this research in order to study the historical background of foundations.

${ }^{10}$ ANHEIER, H. K., DALY, S. "Philamnthropic foundations in modern society", in Foundations in Europe: society, management and law, Routledge, New York, 2007, pp. 8-9. H. K. Anheier, "Foundations in Europe: a comparative perspective”, cit., pp. 41-42.

${ }^{11}$ ANHEIER, H. K. Nonprofit organizations, cit., pp. 305-306.

${ }^{12}$ AnHeIER, H. K. "Foundations in Europe: a comparative perspective", cit., p. 49.

${ }^{13}$ Lantarón Barquín, David. "La Fundación y sus recientes proyecciones en el Derecho del Trabajo y de la Seguridad Social (Especial atención a las Fundaciones Sanitarias)", cit., pp. 173-174.

${ }^{14}$ Ibid.

${ }^{15}$ The term "work foundation" is also used, as a sinonym of "labour foundation".

${ }^{16}$ Currently, it has been highlighted as a practical example of "flexicurity" along with the Austrian severance payment system. European Commission, Communication from the Commission to the European Parliament, the Council, the European Economic and Social Committee and the Committee of the Regions. "Towards Common Principles of Flexicurity: More and better jobs through flexibility and security». COM(2007) 359 final, European Commission, Brussels, 2007, p. 19.

17 "Arbeitsstiftungen", as it is called in German, are highlighted as a successful model for the solution of regional structural and labour market problems. This instrument was first used in the framework of the VOEST-Alpine Steel Foundation (1987).

${ }^{18}$ Winter-EBMER, R. Long-term consequences of an innovative redundancy-retraining project: The Austrian Steel Foundation, Working Paper, Department of Economics, Johannes Kepler University of Linz, 2000, p. 6.
} 
achieving a complex balance between the vindicating industrial workers and their trade unions and the rest of society.

Thus, on the one hand, the Austrian steel industry was no longer economically viable in a context of global concurrence, meaning that massive lay-offs may be adopted, as a first step in an overall renewal process. Some major decisions had to be taken in order to steer this complex process, minimizing both the social effects and the union responses. On the other hand, no sort of answer was going to be understood by a society involved in such a great variety of social, economic and political changes ${ }^{19}$.

The final result is a legal form in which all of these parties are represented but in which the main solutions come from the one that has been the most affected, employers and employees. The establishment of a labour foundation is based on an agreement between social partners at company or sector level in collaboration with the regional labour market service authority ${ }^{20}$. Accordingly, despite the fact that public administration support is going to be needed, as it is being explained, the success of Austrian labour foundations probably comes from the offering of solutions that are supported (and financed) by employers, workers and ex-employees. In these ways, pre-retirement, active job seeking and, most of all, education, training and requalification programs were implemented in order to provide a new labour opportunity to all workers who viewed themselves as having been dismissed (paying special attention to older and young job-seekers).

However, there are other experiences in Europe from which knowledge may also be derived for both European and national good practices perspectives. Spanish labour foundations are one of them. The interest in these foundations is based on two main points. On the one hand, they give us a concrete and specific regulation on labour foundations which comes directly from the law. In this sense, they are based on a completely different legal system as compared to the Austrian experience. On the other hand, they represent the first regulation in Europe on this specific type of foundation. This not only means a longer tradition, but more importantly, that they are based on a completely different socio-economic perspective.

The following sections will be dedicated to analyse their legal framework through one of the most thorough and developed experiences: the case of Construction Labour Foundation of Asturias.

\section{Labour foundations in Spain: the institutional framework}

\subsection{Legal Framework}

Although Spanish labour foundations are not as well known as others, such as the Austrian ones ${ }^{21}$, they are a prototypical example of this type of foundations. Before explaining the legal framework of these institutions in Spain, it may be interesting to present some data describing their situation. This, however, is not an easy task. Despite the fact that Law 50/2002, of 26 December, on Foundations ${ }^{22}$ (hereinafter Law 50/2002) established the creation of a single register of foundations, this was recently carried out ${ }^{23}$. This means that the information still remains distributed between the different public institutions that are in charge of this type of registers, including various national ministries and offices of the Autonomous Communities. Fortunately, some private institutions, like the Spanish Association of Foundations (Asociación Española de Fundaciones -AEF-), attempts to centralize all this information.

According to the AEF's data, there are 14,808 foundations registered in Spain in 2015, of which 13,302 are "active". This data includes all types of foundations, public and private, related to all sorts of activities and purposes, including the environment, culture, entrepreneurship, charity, religion, etc.

Regarding this last one, 232 foundations declare to have "employment and learning" 24 as main activity, whereas 289 as a secondary activity, 185 as a third activity and 73 a fourth. Thus, different types of

\footnotetext{
${ }^{19}$ SuschnigG, P. From Austrian Labour Foundations to Job Transfer: Training Strategies Under Three Labour Relations Regimes, York University, North York (Canada), 2001, pp. 4-11.

${ }^{20}$ Voss, E. Organising Transitions in Response to Restructuring, European Commission, Hamburg, 2010, p. 41.

${ }^{21}$ Mercader Uguina, Jesús R. (ed.), Fundaciones laborales: herramienta para canalizar la responsabilidad social empresarial, Tirant lo Blanch, Valencia, 2009, p. 192.

${ }^{22}$ Spanish Official Gazette (BOE) of $27^{\text {th }}$ December 2002, no. 310.

${ }^{23}$ Order PRE/2537/2015. Spanish Official Gazette (BOE) of $1^{\text {st }}$ December 2015, no. 287.

${ }^{24}$ This is the keyword under which they are classified.
} 
activities and purposes may be undertaken by a single foundation, which means that, some of these foundations may be not be classified as "labour foundation" according to the regulation as explained below.

In order to focus our analysis on those foundations that are in fact "labour", and considering that the available data fails to distinguish them, the foundation names have been used. This strategy is not a complete and satisfying response for two main reasons. On the one hand, there is no obligation to use the term "labour foundation" such as, so it is quite possible that the words "labour" or "work" may not appear in the name. On the other hand, there are some foundations that, although they use this term in their name, are not in fact labour foundations, according to the traditional characteristics described in the Spanish regulations. Despite these problems, it may be a useful way to determine the exact number of labour foundations existing in Spain.

The next graph show this data, distinguishing between those whose scope is the state and those whose activities are developed within the limits of an Autonomous Community (or a province or provinces to which it belongs).

Graph 1. Labour foundations in Spain

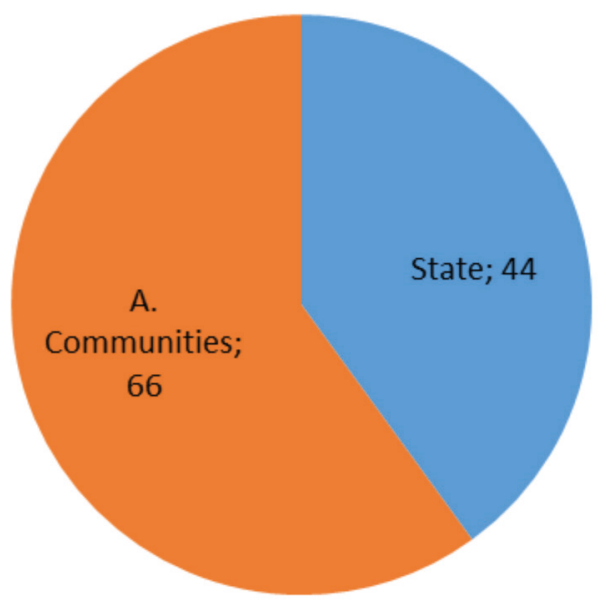

Source: own elaboration based on AEF's data.

Considering that no specific labour foundation regulation exists in the Autonomous Communities, they have been found to be quite successful. As for the overall data, it may be classified as satisfactory, especially when considering the abandon that this type of foundation has suffered over the past decade, which shall be described later. Unfortunately, the scarcity of the data does not permit the creation of a more thorough description, for example, one revealing how many employees are covered by these foundations.

The Spain's case is probably one of the oldest in Europe. The Spanish labour foundation regulation dates back to 1961, when Decree 446/1961, of $16^{\text {th }}$ of March, on labour foundation was passed ${ }^{25}$. Then, the Order of the Ministry of Employment of $25^{\text {th }}$ of January of 1962 created its content ${ }^{26}$. According to its Statement of Reasons, «Over time, there is a greater number of companies which, interpreting their social duties fairly, create charitable organizations within its structure to favour its employees, although they do not usually provide them with any sort of property, legal autonomy or control. The great job that these organizations can offer, not only directly through their activity, but by bringing together the individuals who work in the same place, provides employers and employees formulas that offer stability to this activity, facilitating employee solidarity with the company efforts and contributing to optimal results» ${ }^{27}$. As a result, this tool has been extended across the country, so the new regulation comes to offer legal support and to promote its diffusion ${ }^{28}$.

\footnotetext{
${ }^{25}$ Spanish Official Gazette (BOE) of $20^{\text {th }}$ March 1961, no. 67.

${ }^{26}$ Spanish Official Gazette (BOE) of $13^{\text {th }}$ February 1962, no. 38.

${ }^{27}$ Own translation.

${ }^{28}$ Regarding the historical origins of labour relations, see RuIz OlabuÉnAGA, J. I., "Spain”, in Foundations in Europe: society, management and law, Routledge, New York, 2007.
} 
Although this regulation is inspired by an old fashioned concept of labour relations, typical of Franco's dictatorship that conceives them as a harmonious community between labour and capita ${ }^{29}$, it is also reflects the first steps towards true collective bargaining. This trend shall be seen to have accelerated with the democracy thanks to the Constitution of 1978, whose articles 34 and 37 promote foundations and collective bargaining, respectively ${ }^{30}$. The final result is that labour foundations go from being viewed with suspicion due to their novelty, to be considered an advanced institution of the new period for Foundation Law and collective bargaining ${ }^{31}$.

Consequently, the new Law 30/1994, of $24^{\text {th }}$ November, on Foundations and Tax Incentives for Private Participation in Activities of General Interes ${ }^{32}$ was going to keep the previous regulation, explicitly include «group of workers from one or two undertakings and their relatives» as beneficiaries of a foundation (art. 2.2) and order the renovation of the regulation through a new decree by the Government (additional provision 18).

However, a new law shall substitute the former one with some important changes for labour foundations. The current Law 50/2002, of $26^{\text {th }}$ December, of Foundations ${ }^{33}$ abrogated most of the content of Law 30/1994, including additional provision 18, and the Decree of 1961. This does not means that Labour Foundations no longer exist in Spanish legal systems. Currently, it is possible to find specific mentions, such as art. 2 r) of Law 36/2011 of Social Procedure ${ }^{34}$, expressly including disputes related to labour foundations within labour court competences; art. 240.2 General Social Security Law ${ }^{35}$, which permit undertakings to improve the coverage provided by Social Security through, among other tools, labour foundations; or art. 2.1.d) of Royal Decree 1337/2005, of $11^{\text {th }}$ November, approving the Regulation of state level foundations, which expressly mentioned this kind of foundations and whose first additional provision defines them but only «for the purposes of this regulation» ${ }^{36}$.

Nevertheless, the Law has opted for regulation of labour foundations through a general prescription instead of a specific one. It admits the existence of labour foundations as a specific type of foundations and, consequently, its art. 3.2, concerning beneficiaries, attempts to save one of their most important legal obstacles: «the founding purpose must benefit a generic group of people. This category includes groups of workers from one or several companies and their families» ${ }^{37}$. But, except for this quite important exception, labour foundations must be governed by the same rules as any other foundation. This new regulation was criticized by the doctrine ${ }^{38}$, since it does not deal with the numerous peculiarities of this type of foundation, which would be an obstacle for their future expansion and development.

Consequently, the Spanish legal system maintains the legal form of foundation but with few specific rules. As mentioned previously, along with the legal mention of employees as beneficiaries, Royal Decree 1337/2005 includes the concept of labour foundation:

\footnotetext{
${ }^{29}$ Gala Vallejo, C. "Las fundaciones laborales: (su base ideológica y planteamiento jurídico)", Revista de Previsión Social, vol. 19, 1963, pp. 3-6.

${ }^{30}$ Mercader Uguina, Jesús R. (ed.). Fundaciones laborales, cit., pp. 17-19.

${ }^{31}$ Lantarón Barquín, David. "La Fundación y sus recientes proyecciones en el Derecho del Trabajo y de la Seguridad Social (Especial atención a las Fundaciones Sanitarias)”, Relaciones laborales: Revista crítica de teoría y práctica, 1, 2001, p. 17.

${ }^{32}$ Spanish Official Gazette (BOE) of $31^{\text {st }}$ October 2015, no. 261.

${ }^{33}$ Spanish Official Gazette (BOE) of $27^{\text {th }}$ December 2002, no. 310.

${ }^{34}$ Spanish Official Gazette (BOE) of $11^{\text {th }}$ October 2011, no. 245.

${ }^{35}$ Spanish Official Gazette (BOE) of $29^{\text {th }}$ June 1994, no. 154.

${ }^{36}$ Spanish Official Gazette (BOE) of $22^{\text {nd }}$ November 2005, no. 279. Accordingly, art. 11 a) of Royal Decree 1611/2007, of $7^{\text {th }}$ December, in which the register of state level foundation is created (Spanish Official Gazette (BOE) of 19 ${ }^{\text {th }}$ January 2008 , no. 17) recognizes labour foundations as the kind of institution that may be registered in it. According to Spanish Constitution, both the State and Autonomous Communities are competent to regulate foundation activities in their respective geographical area.

${ }^{37}$ As mentioned previously, the concept sustains that assets must be dedicated to a particular purpose. In some legal systems, only public purposes are admitted, whereas others allow foundations to pursue any lawful purpose, including private ones. However, in these latter situations, public tax benefits are usually excluded. In the case of Spain, only public purposes are admitted, generating a huge debate on the legal nature of labour foundations and whether or not they really are foundations. For more on this debate, see Rodulfo, J., Las fundaciones laborales: problemática actual y régimen jurídico, Grupo INI, Madrid], 1992, pp. 43-48.

${ }^{38}$ Mercader Uguina, Jesús R. Fundaciones laborales, cit., pp. 36-37.
} 
«For the purposes of this regulation, labour foundations are considered to be those:

a) created by agreement between companies and their employees, [or] established by unilateral act of a company or third parties for the benefit of workers of one or several companies and their families.

b) formed by the most representative employers and trade union organizations in a given sector or some specific sectors for the development of working purposes». ${ }^{39}$

Furthermore, the general legal concept of foundation is also applicable (art. 2), defined as a «nonprofit organization whose patrimony or assets, by their founders' wish, is permanently intended for purposes of general interest». According to this definition, three main characteristics delimit the concept of foundation in Spanish Law, not so different from other civil law systems: a patrimony intended for a purpose, that is managed by a specific legal entity and that pursues a general interest as a non-profit organization $^{40}$.

Comparing these two definitions, what are the keynotes of the definition of a labour foundation? Regarding the intended patrimony, it could emerge in two different ways: a) by agreement between companies and their employees; that is, by collective bargaining agreement; or b) by unilateral act of the company or a third party ${ }^{41}$. So, here we have the first genuine characteristic of a labour foundation since, in addition to the unilateral decision or will of one or more individuals, collective bargaining is also a legal method, and in this case, the principal one in order to constitute a foundation ${ }^{42}$. Moreover, it has some major legal consequences since it connects the labour foundation to the right to collective bargaining (art. 37 of the Spanish Constitution -SC-) and, specially, to freedom of association (art. 28 $\mathrm{SC}$ ), which is more protected as a fundamental right. In other words, labour foundations extend beyond the limits of art. 34 of SC, linking not only to other rights, but to the one having the greatest protection in Spanish legal system, as a part of the activities that may be carried out by trade unions.

This singular via is articulated by the direct agreement between the employer and his employees (or employees' representatives) or by agreement between the most representative employers and trade union organizations in a given sector or several specific sectors. Is should be highlighted that any type of collective agreement is valid to constitute a labour foundation. Each case refers to two different bargaining levels, company level and sectorial level. As we shall explain below, this latter one is especially important for small and medium sized enterprises (hereinafter, SME) since it permits them to profit from synergies derived from the economies of scale.

Second, regarding the purpose itself, there are two main limits or requirements. On the one hand, it must be a «purpose of general interest» (general requirement) but, on the other hand, «for the benefit of workers of one or several companies and their families» or «the development of working purposes » (specific requirements). This means that all sorts of purposes admitted for any kind of foundation will be valid for a labour foundation if it benefits company employees and their families or working purposes. The definition of a "purpose of general interest" is not limited by Law 50/2002, but rather, it offers an extensive list including, among others, those related to social assistance and social inclusion, education, culture, science, health, employment or promotion of social economy ${ }^{43}$. The previous Decree from 1961 mentioned assistance "work" or activities as inherent to labour foundations. However, it also included an open list that probably connected those that were more common in that particular time: «kindergar-

\footnotetext{
${ }^{39}$ First Additional Provision of Royal Decree 1337/2005. Own translation. This concept does not contain the Autonomous Communities that have competences on foundations placed in their territories. Andalucía, Canarias, Castilla y León, Cataluña, Galicia, La Rioja, Madrid, the Basque Country and the Valencia Community have passed their own laws on foundations. Source: Spanish Association of Foundations (AEF).

${ }^{40}$ DrobNig, U. "Foundations as Institutionalized Charitable Activity", in Foundations in Europe: society, management and law, Routledge, New York, 2007, pp. 608-611.

${ }^{41}$ This "bilateral" way of conforming labour foundations comes from the first regulation. In spite of that art. 3 of Royal Decree 446/1961 only mentioned the agreement between the company and workers, the subsequent Order also included unilateral acts of the employer or a third party (art.2).

${ }^{42}$ Gala Vallejo, C. "Las fundaciones laborales", cit., p. 8.

${ }^{43}$ See art. 3.
} 
tens, schools, holiday and retirement homes, recreational, cultural and vocational training centres, company shops, sports facilities, medical services or other healthcare facilities, fellows, housing and generally any other kind of assistance activities for the benefit and enjoyment of those who serves or served in a company $\rangle^{44}$. It should be noted that both the Law and current Decree refer simply to "employees", but does not mention former employees, as did the 1961 Decree, raising a question as to whether labour foundations could develop programs for workers who have been dismissed ${ }^{45}$.

Some studies have highlighted the fact that the Spanish definition differentiates between levels of bargaining. At a sectorial level, the purposes have broader names («employment purposes») and there is only one way to create a foundation: the collective agreement. At a company level, the purposes appear to be more reduced («benefit of workers of one or several companies and their families») and the paths are more diverse, not only collective agreements, but also unilateral acts of the employer or a third person. This differentiation is used to highlight the fact that, in the second case, the beneficiaries need only to be considered employees in order for them to be considered "labour foundations" 46 .

Accordingly, Spanish regulation establishes a set of requirements which makes labour foundations different to the rest of them. On the one hand, at company level, the minimum requirement is benefiting workers and their families (and, additionally, it may be created by collective agreement). On the other hand, at sectoral level, the entity must be founded by collective agreement. This is a genuine characteristic element of labour foundations.

From a comparative perspective, a third keynote can be added ${ }^{47}$ : employees or, more correctly, their representatives, must take part in the management of the foundation. This is the logical consequence when the foundation is constituted by collective agreement; that, as we previously mentioned, is the most common situation, but the Law does not impose it. The former Decree of 1961 obligated the inclusion of worker representation in the foundation's compulsory government organs ${ }^{48}$. This characteristic led to some major legal debates since, from a theoretical point of view, the foundation manager is usually the administrator of a tool, the foundation, from which a third party profits. In the case of labour foundations, not only are employee representatives the administrators, but also the founders and beneficiaries, raising the question of whether or not this is contradictory with the legal nature of foundations. In order words, questioning whether or not labour foundations are real foundations.

These debates have been addressed by Law 50/2002 which, as was previously mentioned, expressly says that «groups of workers of one or several companies and their families» may be considered a generic group for the purpose of the foundation, that is, they may be beneficiaries. Furthermore, since there is no rule that forbids their participation in the management of the labour foundation, this means that ope legis, there are no obstacles to the participation of employee representative in the foundation's organs of government. Aside from the law, this has been justified by the fact that neither general interest means the interest of a group of beneficiaries, nor can managers do whatever they choose outside the foundation agreement. Accordingly, a foundation cannot be created to satisfy the private interests of a group of beneficiaries nor may its managers adopt decision that are contrary to foundations agreement ${ }^{49}$. In addition, both creation and administration are shared activities, so not only may the employee representatives participate, but the employer as well. Their presence guarantees the public purpose of the foundation and that founder and manager interest do not coincide with that of the beneficiaries. Regardless, it is quite possible that, as warned, this is a special and specific characteristic of labour foundations ${ }^{50}$.

\footnotetext{
${ }^{44}$ Art. 1 Royal Decree 446/1961.

${ }^{45}$ Nevertheless, it may be admitted as "working purpose" for the sectoral level.

${ }^{46}$ Mercader Uguina, Jesús R. (ed.). Fundaciones laborales, cit., p. 177.

${ }^{47}$ Pérez del Prado, D. "What is a labour foundation? A comparative perspective", (en prensa), 2016.

${ }^{48}$ Art. 4 and art. 24 Order of $22^{\text {nd }}$ January 1962.

${ }^{49}$ Mercader Uguina, Jesús R. (ed.). Fundaciones laborales, cit., pp. 45-46.

${ }^{50} \mathrm{Ibid}$., p. 46. This interpretation coincides with those that, in the international panorama, underlie the fact that the foundation's purposes tend to be more changing and flexible. Prewitt, K., "The Foundation Mission: Purpose, Practice, Public Presures", in Foundations in Europe: society, management and law, Routledge, New York, 2007, pp. 351-357.
} 


\subsection{Construction Labour Foundation of Asturias: the reference case}

There are some significant examples of labour foundations in Spain which reveals that they are capable of providing quite a wide range of activities within the limits of employment relations. Whereas other comparative experiences developed out of a very specific context for a very specific purpose, subsequently extending their activities in the field of employment policies, Spanish labour foundations were created to develop different types of activities related to social protection, working conditions, employment policies and corporate social responsibility, among other tasks.

This characteristic is one of the most significant in order to classify Spanish work foundations as a different version of this type of institutions in Europe, a second type if they are compared to other experiences. Therefore, it is possible to say that there are, at least two different types of labour foundations, based on the activities that they are currently carrying out. On the one hand, there are the "growinglimits" foundations, referring to those whose purposes fall within the limits of employment policies. On the other hand, there are the "open-limit" or "flexible" foundations, whose limits are more extensive, although though their activities must refer to employment or industrial relations.

In order to justify this classification and, more importantly, to reveal the type of activities that labour foundations may carry out, which may be useful for legal systems and labour markets as good practices, one of the most highlighted cases ${ }^{51}$ has been selected. This is the Construction Labour Foundation of Asturias ("Fundación Laboral de la Construcción del Principado de Asturias" - hereinafter, the FLCA-), which is defined as a "non-profit joint organism of a social and labour nature". It was created in 1988 through a specific clause included in the Collective Agreement for the Construction Sector in Asturias $^{52}$, signed that year by the employers' regional associations (Confederación Asturiana de la Construcción (CAC) and Asociación de Promotores y Constructores de Edificios Urbanos de Gijón (ASPROCON)) and the two principle trade unions (CCOO and UGT). This foundation is mainly aimed at employees who are covered by this collective agreement and their families, but it also expands its scope to unemployed individuals from the construction sector and other collectives if the programs related to them produce any kind of benefit for the construction sector.

The FLCA's activities are financed by employer contributions ( $4.5 \%$ of the gross wage costs). This obligation was created by the collective bargaining agreement and it affects all of the companies under its scope of application. Despite the fact that this is the main source of funds, the FLCA also receives some public grants and other resources from financial and commercial activities.

The contribution system is quite sophisticated ${ }^{53}$. Contribution depends on the number of hired workers and days during they are working. In order to control these two elements, the FLCA signed a co-operation agreement with the Social Security Fund. Currently, the procedure followed by companies is inspired by the Social Security contribution procedure. Thanks to this agreement, the FLCA can compare the information declared by the companies in its "virtual office" with that which is registered in the Social Security database. Every month, the FLCA provides companies with a proposal of contributions. In the case of disagreement, the company may submit a rectification form which shall be revised in a period of 15 days. The entire procedure is followed electronically by the "virtual office".

These contributions are used to finance two independent funds: first there is the so-called "general fund", destined to the FLCA's assistance and ordinary activities; and second is the "special fund", which supports the "sector loyalty" benefits as described below.

Therefore, the funds controlled annually by the FLCA depend on the number of workers and companies who are direct beneficiaries of its activities according to the collective bargaining agreement. The following table and graph show both of these as well as the evolution during the crisis. They both distin-

\footnotetext{
${ }^{51}$ This foundation has been recognised by the EU Council as a Model of Good Practices in the application of EU Guidelines for Employment (Helsinki, 1999). Council of the European Union, Joint Employment Report 1999. Part I. The European Union, Council of the European Union, Brussels, 1999.

${ }^{52}$ The "Principado de Asturias" (Principality of Asturias) or simply "Asturias" is an Autonomous Community situated in the north of Spain. Its total population is around 1,000,000 inhabitants.

${ }^{53}$ For more details see FLCA, Manual de cotización a la Fundación Laboral de la Construcción del Principado de Asturias, Principality of Asturias, 2009. Principality of Asturias Official Gazette (BOPA) of $12^{\text {th }}$ January 2009, no. 8.
} 
guish between employees who are under the coverage of the collective bargaining agreement of Asturias (CBAA) and the other collective bargaining agreements which are also applied in the construction sector in Asturias (OCBA) and to freelance workers. The table also shows the percentage of each group.

Table 1. Companies and workers beneficiaries of the FLCA and entire construction sector.

\begin{tabular}{|l|c|c|c|c|c|c|c|c|}
\hline & Companies & \multicolumn{4}{|c|}{ Employees } & \multicolumn{3}{c|}{ Employees \% } \\
\hline & CBAA & CBAA & OCBA & S-E & Total & CBAA & OCBA & S-E \\
\hline December 2007 & 3,669 & 30,896 & 7,702 & 11,884 & 50,482 & $61.20 \%$ & $15.26 \%$ & $23.54 \%$ \\
\hline December 2008 & 3,334 & 25,273 & 6,564 & 11,405 & 43,242 & $58.45 \%$ & $15.18 \%$ & $26.37 \%$ \\
\hline December 2009 & 3,001 & 22,714 & 6,977 & 10,938 & 40,629 & $55.91 \%$ & $17.17 \%$ & $26.92 \%$ \\
\hline December 2010 & 2,541 & 18,428 & 7,963 & 10,342 & 36,733 & $50.17 \%$ & $21.68 \%$ & $28.15 \%$ \\
\hline December 2011 & 2,362 & 15,346 & 5,908 & 9,984 & 31,238 & $49.13 \%$ & $18.91 \%$ & $31.96 \%$ \\
\hline December 2012 & 1,916 & 11,036 & 5,070 & 9,144 & 25,250 & $43.71 \%$ & $20.08 \%$ & $36.21 \%$ \\
\hline December 2013 & 1,659 & 9,218 & 5,161 & 8,748 & 23,127 & $39.86 \%$ & $22.32 \%$ & $37.83 \%$ \\
\hline December 2014 & 1,559 & 8,355 & 5,846 & 8,779 & 22,980 & $36.36 \%$ & $25.44 \%$ & $38.20 \%$ \\
\hline December 2015 & 1,530 & 7,844 & 6,698 & 8,956 & 23,498 & $33.39 \%$ & $28.50 \%$ & $38.11 \%$ \\
\hline January 2016 & 1,495 & 7,617 & 6,475 & 8,855 & 22,947 & $33.19 \%$ & $28.22 \%$ & $38.59 \%$ \\
\hline
\end{tabular}

Source: FLCA Memory 2015. CBBA: Collective Bargaining Agreement for Asturias. OCBA: Other Collective Bargaining Agreement. S-E: Self-Employment.

Graph 2. Evolution of the number of beneficiaries, companies and workers.

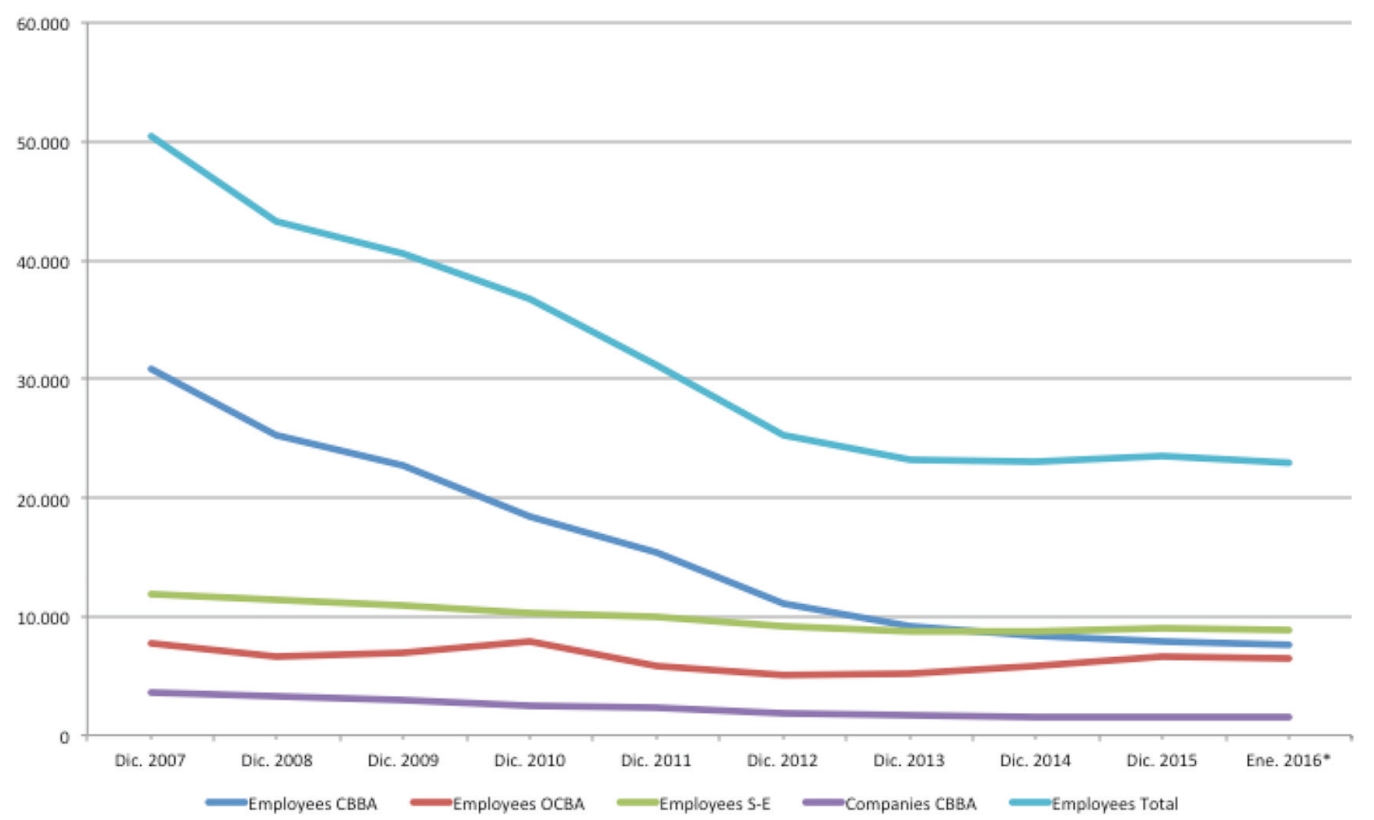

Source: FLCA Memory 2015. CBBA: Collective Bargaining Agreement for Asturias. OCBA: Other Collective Bargaining Agreement. S-E: Self-Employment.

First, the data reveals the effects of the crisis on the construction sector, probably the most harshly affected in Spain, reducing both the number of companies and employees. This authentic "earthquake" has reduced the number of companies by $145 \%$ and altered the traditional distribution of employees. As job destruction has mainly focused on dependent work, more than on self-employment, and the percentage of workers affected by the collective agreement of Asturias (and beneficiaries of FLCA activities) has change notably. Hence, from covering over 30,000 workers ( $61 \%$ of total employees) prior to the crisis, this number has been reduced to approximately 7,600 workers (33\% of total) in 2016. 
However, despite the impact of the crisis, the FLCA continues to assist a relatively high number of companies and employees within the construction sector in this Autonomous Community. Approximately 1,500 companies devote their contributions to the support of FLCA activity, which assists more than just the mentioned number of workers, given that it also implements programs for the unemployed. Moreover, the incipient economic recovery leads us to believe that the FLCA shall return to its usual level of coverage in relative terms or based on percentages ${ }^{54}$, since in the past, it was quite stable.

Their purposes have been defined quite broadly, inspired by the Decree of 1961, but all of them may be summarized in the five main areas highlighted as the primary in the practical functioning of Spanish labour foundations ${ }^{55}$.

First, the FLCA offers social benefits to enhance or complement social security benefits. In addition to the complementary temporary disability benefits ${ }^{56}$, quite common in the Spanish collective bargaining, the FLCA also provides family allowances, the so-called "sector loyalty" benefit and subsidies for long-time unemployed workers. This first one is directed to cover distinct circumstances that may directly affect the worker, such as disability, death or education; or that relate to the worker's family, such as having minors or children who are studying or the death or disability of a spouse or child. From 2012 to 2015 , approximately 3,000 benefits were provided on average per year, having a maximum quantity of 3,500 euros. The total costs approximate 1,000,000 euros.

The second recognizes the permanence of the employer in the construction sector. The FLCA is also responsible for paying the seniority bonus by compensating its cost to the companies that recognize it. This is a means of helping to secure employment by providing financial assistance to workers with seniority. Moreover, this mechanism has been highlighted because it enables a redistribution of seniority labour costs within the sector and thereby ensures more balanced competition between companies ${ }^{57}$. In 2014, the total number of beneficiaries was 10,019 ; the average daily subsidy was 0.78 euros and the total cost reached more than 2,000,000 euros. The second measure benefited 80 undertakings with a cost of $148,581.15$ euros $^{58}$.

The third refers to long-time unemployed workers who were dismissed by a company under the coverage of the collective agreement from prior to the $31^{\text {st }}$ of December 2007. The potential beneficiary must not be entitled to receive any type of unemployment benefit from the social security system. This subsidy is related to the attendance to a free vocational training course and its amount depends upon the number of hours of this activity, reaching a maximum of 680 euros. Despite its attractive design, which was inspired by the latest trends in the activation of passive employment policies, the funds dedicated to this program have been affected by the crisis. So, from the 330 beneficiaries and more than 97,000 euros for the period 2011-2012, these figures were reduced to 35 and approximately 18,000 euros in 2013.

Second, learning programs are one of the most often supported by labour foundations in Spain and the FLCA is a significant example of this. It has created two learning centres that specialize in vocational training for the hiring sector. These centres offer courses for employees, unemployed people and young students, adapting them to the company needs and requirements. Special program for longtime unemployed individuals were explained previously. As for the other programs, 34 courses were offered for young people in 2014, benefiting a total of 427 students. However, the effects of the crisis have emerged here as well. The average number of students over the last two decades is 1,099 , peaking to 4,316 in 2011; and the average number of courses is 90 , peaking at 385 during this same year. Thus, the reduction is quite pronounced. As for vocational training for workers, 79 courses were developed in 2014, assisting 864 employees. The trend is exactly the same as with the previous program, showing a

\footnotetext{
${ }^{54}$ However, it is quite unlikely that the construction sector shall employ the number of workers that it did several years ago, either in Asturias or in Spain.

${ }^{55}$ Mercader Uguina, Jesús R. (ed.). Fundaciones laborales, cit., pp. 141-157. To examine the FLCA's activities in greater detail, see FLCA, Memoria de actividades 2015, FLCA, 2016.

${ }^{56}$ Spanish temporary disability benefits cover this type of risk with the $60 \%$ of the insured's daily average earnings in the last calendar month before the incapacity began, paid from the 3rd to the 20th day; and $75 \%$ from the 21 st day for up to 12 months (but it may be extended for six months). Collective bargaining agreement used to complement both days and quantities. In this case, the labour foundation is used as a tool to implement it.

${ }^{57}$ Council of the European Union, Joint Employment Report 1999. Part I. The European Union, cit., p. 96.

${ }^{58}$ Data for 2013.
} 
considerable decrease if compared with the averages from the last two decades: 140 courses and 1,753 beneficiaries. This is particularly disturbing when considering that the evaluation of these programs, mainly focused on the effectiveness of training for labour market integration, has shown the positive effect of trainings adapted to the company needs, having a placement of trainees that approximates $74 \%{ }^{59}$.

In addition, the foundation has also created the so-called "professional construction card" and the "professional construction card for self-employed persons" that is, a document that credits, among other data, the training received by the worker in the area of occupational risk prevention and that is required by law in order to work in this sector ${ }^{60}$. This special effort made in education and training has been recognized as a good practice by the most specialized entities ${ }^{61}$.

The third large area is known as "social action", that is, a heterogeneity group of benefits that provide economic aid or services that are not directly connected with labour or guaranteed by law ${ }^{62}$. Here, the FLCA is in charge of providing scholarships and aid-assistance for the disabled; promoting research and development programs or improving the scientific and technical research in the field of construction; conceding allowances for rehabilitation or access to the first home; implementing programs on the use of new technologies, with special attention to computer and telecommunications, etc.

The program dedicated to the rehabilitation or access to the first home should be recognized, given its links to social aid to the general strategy of economic policy for this sector. With this instrument, the construction sector re-invests some of its profits in itself, contributing to its expansion, particularly during the recession period. Moreover, after this, it may help with the reorientation of the sector to other types of activities such as rehabilitation, thanks to the changes introduced in 2011. The allowances have varied from 2,000 to 6,000 per beneficiary and project and they may permit investment of more than 66,000 euros in 2015. This program has led to the inversion of over 9,000,000 euros in the sector during the last 15 years.

Fourth, employment policies and labour intermediation are other activities that are carried out by the FLCA, revealing that its purposes extend beyond only workers of the construction sector, also including the unemployed and young job-seekers. Some of the measures developed in this area have already been explained. Nevertheless, other important initiatives should also be described. Hence, the FLCA has its own employment agency, which collaborates with the regional public employment service and has a relative high placement rate: $62 \%$ of the job offers currently filled by the agency were attained by their trainees ${ }^{63}$.

In this field, some hiring incentive programs have also been developed to provide support to vocational training students. Despite the empirical evidence suggesting the inefficiency of this type of policy in Spain ${ }^{64}$, given its large "deadweight effect", it would be interesting to evaluate this program, since it focuses on a very specific collective. This and the fact that the program focuses on individuals receiving training may lead to different results ${ }^{65}$.

Another initiative related to this type of policy is the so called "Program for the maintaining of employment 2013-2016", which incurred costs of 198,000 euros in 2014 and 165,000 in 2015. It was developed within the framework of the social dialogue between the parties of the collective bargaining

\footnotetext{
${ }^{59}$ Council of the European Union, Joint Employment Report 1999. Part I. The European Union, cit., p. 97.

${ }^{60}$ Actually, the Spanish "Fundación Tripartita para la formación en el empleo" (Tripartite Foundation for Vocational Training) centralizes the main effort in the area of vocational training and education for both employees and unemployed people in Spain. The presence of the Public Administration in its foundation and management has been used to exclude it from the group of "labour foundations". Jesús R Mercader Uguina (ed.), Fundaciones laborales, cit., pp. 136-137. However, it is officially registered as such and, considering the rules exposed here, there would be any problem in classifying as labour foundation. Its results have been highlighted as a good practice. P. Szovics; European Centre for the Development of Vocational Training (eds.), Sectoral training funds in Europe, Office for Official Publ. of the Europ. Communities, Luxembourg, 2008, pp. 51-70.

${ }^{61}$ P. Szovics. European Centre for the Development of Vocational Training (eds.), Sectoral training funds in Europe, cit., pp. 71-78.

${ }^{62}$ Martín Valverde, A. Las mejoras voluntarias de seguridad social, Instituto García Oviedo. Universidad de Sevilla, 1970, p. 17.

${ }^{63}$ Council of the European Union, Joint Employment Report 1999. Part I. The European Union, cit., p. 97.

${ }^{64}$ Toharia CorTés, L. (DIR) y otros, El efecto de las bonificaciones de las cotizaciones a la Seguridad Social para el empleo en la Seguridad Social: un intento de evaluación macroeconómica, microeconómica e institucional, Ministerio de Trabajo e Inmigración. Secretaría de Estado de Seguridad Social, 2008. Pérez del Prado, D., Los instrumentos económicos de fomento del empleo, Tirant lo Blanch, Valencia, 2011.

${ }^{65}$ MoOre, J. y otros, Stimulating job demand the design of effective hiring subsidies in Europe. 2014. 2014., Publications Office, Luxembourg, 2014, pp. 44-49.
} 
agreement and aims to maintain current employment levels in the construction sector in Asturias. It consists of a subsidy for companies in the sector whose amount depends on the number of workers and days they have worked over a specific period of time. Currently, the main requirements are maintaining the level of employment and the working conditions as agreed upon in the collective agreement, especially those related to salary $\left.{ }^{(66}\right)$.

Finally, of the activities carried out by the labour foundation, those related to occupational risk prevention are quite common. Programs developed by the FLCA range from the area of education and training, as previously mentioned, to inspection activities, in collaboration with the Employment and Social Security Inspectorate. In 2015, 2,942 construction sites were visited and 3,732 inspections were carried out. This means that the working conditions of over 8,000 workers were reviewed. These inspections resulted not only in the correction of detected anomalies, but also the creation of practical reports on the status of the sector, offering suggestions to both companies and public authorities, in order to improve occupational risk prevention and the application of Labour Law rules.

The practical impact of these reports is potentially quite high, given that they consider the issues analysed in them and since these analyses come directly from the parties working together in the sector: employers, employees and public administrations. For example, the "Report on the situation of the construction sector in Asturias 2015" "“Informe sobre la situación del sector de la construcción de Asturias 2015) $\left({ }^{67}\right)$ summarizes a list of requirements and suggestions for the public administration in order to improve working conditions, among other issues, in the Asturias construction sector.

Regarding the former, the Administrations are required to publish the concession of contracts and licences in their websites, in accordance with Law 19/2013, of $9^{\text {th }}$ December, of Transparency $\left({ }^{68}\right)$; to obey the limits on subcontracting that were also imposed by the Law $\left({ }^{69}\right)$, to sanction companies that do not fulfil the law, especially the obligations related to labour conditions, social security, labour risk prevention and taxes; to develop inspectorate activities focused primarily on outsourcing; to make sure that companies have at least $30 \%$ of their employees with an indefinite contract, etc.

The report also offers some suggestions, requesting clauses in public contracts to prevent breaches of working conditions or practices leading to their degradation (or others linked to environment and sustainability); the creation of the party "responsible for the contract", who shall be in charge of monitoring and controlling outsourcing; the connection of the objectives of the Employment Strategy with the requirements to obtain a public contract or the conditions to develop any kind of construction, etc.

All of these initiatives demonstrate the huge variety of activities currently being carried out by labour foundations in Spain. It is true that the FLCA is probably a prototypical case, but it success must be taken into account in order to improve the results of labour foundations in Spain or in other countries, adapting the activities that they carry out or creating new programs that permit them to explore new fields. The potential of labour foundations in our changing system of employment relations is enormous. We shall refer to it in the next section when drawing conclusions.

\section{Conclusions: the potential of labour foundations}

This example of FLCA demonstrates that the solution to a large part of the labour problems of modern societies shall come from the social partners directly. The European Union and most States give social dialogue a special role within the framework of labour and social conditions, as the key to obtain the practical balance between competitiveness and welfare that our European social model demands. The solution to combine employers and employees' requirements and needs shall be found in the parties envolved, and labour foundations are its practical materialization.

\footnotetext{
${ }^{66}$ FLCA, Plan de apoyo al mantenimiento del empleo (2013-2016). Reglamento, FLCA, Principality of Asturias, 2013.

${ }^{67}$ See Fundación Laboral de la Construcción del Principado de Asturias, Informe de situación del sector de la construcción del Principado de Asturias 2015, FLCA, 2015.

${ }^{68}$ Spanish Official Gazette (BOE) of $10^{\text {th }}$ December 2013, no. 295.

${ }^{69}$ These two requirements seem to be obvious; especially when considering that it is a public administration. However, practical experience shows that it is absolutely necessary according to the perspective of the social partners.
} 
Nevertheless, they are neither well-known nor receiving sufficient support. The Spanish case is paradoxically an example of success in spite of the fact that the regulation has given up recognizing its peculiarities. Additionally, a specific and particular treatment in the labour, social security and fiscal fields is also missed nowadays.

This different model of work foundation compared to the Austrian, as the best well known, gives us a new reason to remove the obstacles that difficult its development and promote them among companies and sectors all over Europe, as a useful way to improve competitiveness, social dialogue and labour conditions in our continent. The main role of labour foundations in our society can now be divided in three different ones:

First, they are an instrument for the promotion of social dialogue, which in European employment policies, is of great importance $\left({ }^{70}\right)$. Labour foundations permit a better, closer and stronger relationship between employers and employees, which consequently is not concentrated when the collective bargaining agreement must be negotiated, but it extends itself a long time. It permits, not only analysing and finding practical solutions for the different problems of one economic sector between the two main parties involved, but providing useful information for each one. Employers will know the labour and social condition of their employees and employees will take advantage of companies and sector information.

In this sense, the labour foundation is a legal instrument that perfectly connects to the idea of "flexicurity" since among its activities there are both those related to more flexible labour markets and those that look for increased social protection and security $\left({ }^{71}\right)$. Here we have a tool on hand for those who are closer to the labour market, the social partners, which can serve both the employers' and employees interest. Moreover, it is considered to strengthen the daily relationship between them with the labour foundation becoming an ideal instrument to find a balance between competitiveness and welfare and social protection.

Second, labour foundations are tools for corporate social responsibility. This is not only because some of them contributes to some social programs that extend beyond the company or one specific economic sector, such as those for the unemployed or the disabled. Contributing to vocational training or research and development, labour foundations may improve the economic situation of the company, its productivity or competitiveness. Investing in education, they are not only developing a useful program for a company or a sector, but also for society as a whole. Implementing social benefits for their employees and families or even, for unrelated individuals, they act as tools that show that company interests may go beyond mere profit earning. They promote a closer relation not only with the personal and social situation of employer, but with all of society.

Some research has suggested that one of the areas where labour foundations may potentially be extended in the future is in its use as an investment fund $\left({ }^{72}\right)$. This may be materialized as a joint fund, in which both the employer and the workers finance different types of programs related to the foundation's objective. The already-mentioned FLCA would be a good example of this. However, this can be also be crystalized in a company's investment fund in which the undertaking's surplus is used to promote the same sort of activity, but with the important fact that workers or their representative participates in determining the use of this fund. In this way, corporate social responsibility is connected with the improved and more active participation of social partners.

Last but not least, they are a tool to improve SME conditions. When sectoral collective agreements create a foundation for a specific geographical area and/or activity, they may provide services and programs that the SME would be unable to obtain or finance on their own. This is a clear case in which the SME may profit from the scale economies generated by a supra-level institution such as the labour foundation. This is especially important in the vocational training area. Programs are usually quite expensive for these types of companies, but foundations may offer them at an affordable cost. It is

\footnotetext{
${ }^{70}$ European Commission, Communication from the Commission: «Partnership for change in an enlarged Europe-Enhancing the contribution of European social dialogue», European Commission, Brussels, 2004. European Commission, Communication from the Commission: "The European social dialogue, a force for innovation and change», European Commission, Brussels, 2002.

${ }^{71}$ GAZIER, B. "Flexicurity and social dialogue, European ways", University Paris, vol. 1, 2006.

${ }^{72}$ Rodulfo, J. Las fundaciones laborales, cit., pp. 32-36.
} 
true that governments usually plan programs for SME, considering this context, but even in these cases, the foundations may serve as a sort of agent of change, concentrating funds and distributions amongst companies within the sector. Furthermore, these companies may participate in the foundation's activities through their representatives, and, thereby, determine the type of program that best suits their needs.

All of these reasons serve to explain why labour foundations may be an efficient tool to achieve a balance between employer and employee interests, labour flexibility and job security or business profitability and social responsibility. An old and not very well-known instrument for the economic and social challenges of our current society.

\section{Bibliography}

ANHEIER, H. K. "Foundations in Europe: a comparative perspective", en Foundations in Europe: society, management and law, The Directory of Social Change, London, 2001.

ANHEIER, H. K. Nonprofit organizations: theory, management, policy, Routledge, London ; New York, NY, 2005.

ANHEIER, H. K.; DALY, S. “Comparing foundations visions", en Foundations in Europe: society, management and law, Routledge, New York, 2007.

AnHeIER, H. K.; DALY, S. "Philamnthropic foundations in modern society", en Foundations in Europe: society, management and law, Routledge, New York, 2007.

ANHEIER, H. K.; DALY, S. "Comparing foundation roles", en Foundations in Europe: society, management and law, Routledge, New York, 2007.

Council of the European Union. Joint Employment Report 1999. Part I. The European Union, Council of the European Union, Brussels, 1999.

Drobnig, S. "Foundations as Institutionalized Charitable Activity", en Foundations in Europe: society, management and law, Routledge, New York, 2007.

Esping-Andersen, G. The three worlds of welfare capitalism, Princeton University Press, Princeton, N.J., 1990.

European Commission. Communication from the Commission: «Partnership for change in an enlarged Europe-Enhancing the contribution of European social dialogue», European Commission, Brussels, 2004.

European Commission. Communication from the Commission: «The European social dialogue, a force for innovation and change», European Commission, Brussels, 2002.

European Commission. Communication from the Commission to the European Parliament, the Council, the European Economic and Social Committee and the Committee of the Regions. "Towards Common Principles of Flexicurity: More and better jobs through flexibility ans security». COM(2007) 359 final, European Commission, Brussels, 2007.

European Foundation Centre. Comparative Highlights of Foundation Laws. The Operating Environment for Foundations in Europe, EFC, Brussels, 2015.

FLCA. Informe de situación del sector de la construcción del Principado de Asturias 2015, FLCA, 2015.

FLCA. Manual de cotización a la Fundación Laboral de la Construcción del Principado de Asturias, Principado de Asturias, 2009.

FLCA. Memoria de actividades 2015, FLCA, 2016.

FLCA. Plan de apoyo al mantenimiento del empleo (2013-2016). Reglamento, FLCA, Principality of Asturias, 2013.

Gala Vallejo, C. "Las fundaciones laborales: (su base ideológica y planteamiento jurídico)", Revista de Previsión Social, vol. 19, 1963.

Gazier, B. "Flexicurity and social dialogue, European ways", University Paris, vol. 1, 2006.

Lantarón Barquín, D. "La Fundación y sus recientes proyecciones en el Derecho del Trabajo y de la Seguridad Social (Especial atención a las Fundaciones Sanitarias)", Relaciones laborales: Revista crítica de teoría y práctica, n. ${ }^{\circ}$ 1, 2001, pp. 169-196. 
Martín Valverde, A. Las mejoras voluntarias de seguridad social, Instituto García Oviedo. Universidad de Sevilla, 1970.

Mercader Uguina, J. R. (ed.). Fundaciones laborales: herramienta para canalizar la responsabilidad social empresarial, Tirant lo Blanch, Valencia, 2009.

Moore, J.; Manoudi, A.; Scott, D.; Arora, L.; Farrell, J.; O’Muincheann, S. y otros. Stimulating job demand the design of effective hiring subsidies in Europe. 2014. 2014., Publications Office, Luxembourg, 2014.

Pérez del Prado, D. Los instrumentos económicos de fomento del empleo, Tirant lo Blanch, Valencia, 2011.

Pérez del Prado, D. "What is a labour foundation? A comparative perspective", (en prensa), 2016.

Prewitt, K. "The Foundation Mission: Purpose, Practice, Public Presures", en Foundations in Europe: society, management and law, Routledge, New York, 2007.

Rodulfo, J. Las fundaciones laborales: problemática actual y régimen jurídico, Grupo INI, Madrid], 1992.

Ruiz Olabuénaga, J. I. "Spain”, en Foundations in Europe: society, management and law, Routledge, New York, 2007.

Suschnigg, P. From Austrian Labour Foundations to Job Transfer: Training Strategies Under Three Labour Relations Regimes, York University, North York (Canada), 2001.

Szovics, P. CEDEFOP (eds.), Sectoral training funds in Europe, Office for Official Publ. of the Europ. Communities, Luxembourg, 2008.

Toharia Cortés, L. (dir); Arranz, J. M.; Cebrián, I.; García Serrano, C.; Hernanz, V.; Pitarch, J. El efecto de las bonificaciones de las cotizaciones a la Seguridad Social para el empleo en la Seguridad Social: un intento de evaluación macroeconómica, microeconómica e institucional, Ministerio de Trabajo e Inmigración. Secretaría de Estado de Seguridad Social, 2008.

Voss, E. Organising Transitions in Response to Restructuring, European Commission, Hamburg, 2010.

Weisbrod, B. A. The nonprofit economy, Harvard University Press, Cambridge, Mass., 1988.

WINTER-EBmeR, R. Long-term consequences of an innovative redundancy-retraining project: The Austrian Steel Foundation, Working Paper, Department of Economics, Johannes Kepler University of Linz, 2000. 